\title{
Effect of Education, Unemployment, Health Level, and Human Development Index on Economic Growth in South Sulawesi Province
}

\author{
Muhammad Dinar, ${ }^{1, *}$, Muhammad Hasan ${ }^{2}$, Nur Arisah ${ }^{3}$ \\ 1,2,3 Department of Economics Education, Faculty of Economics, Universitas Negeri Makassar \\ ${ }^{*}$ Corresponding author.Email: m.dinar5908@unm.ac.id
}

\begin{abstract}
Macroeconomics is the study of economic activities in a country. The purpose of this study is to examine the effect of education, unemployment, health levels, and the human development index on economic growth in South Sulawesi. This study uses the multiple regression method whose data are taken from 2009-2018. Finally, this study shows that the variables of education, unemployment, and health have no significant effect on economic growth, while the human development index variable has a significant effect on economic growth.
\end{abstract}

Keywords: education, unemployment, health level, human development index, and economic growth

\section{INTRODUCTION}

Economic growth is one of them contained in indicators that function to assess the success of development in a country, especially to provide analysis results on economic development in the region or country. economic growth is an increase in the capacity of a country in the long term and the country is involved in preparing every economic good that is used for the people of that country. This capacity increase can be determined by the speed of technological progress in a particular area. In measuring the progress of development carried out as a whole or broadly, it is necessary to have an indicator of the level of education, the human development index, the level of health as well as the unemployment rate and others. Although the indicator does not directly or directly have a correlation to the level of income per capita [1].

Several previous studies have examined this matter which is related to education level, human development index, health level and unemployment rate to economic growth. In a theoretical study of human capital, education has an influence on economic growth through labor productivity and skills improvement [2]. The contribution of education to economic growth goes back to a theoretical model which provides a broad analysis of the correlation between economic growth and education, first research from Berg, Hendrik [8], Han, G., K.P. Kalirajan, and N. Singh [3]; Dahl, Gordon B.
[4]; Banda H. [5 ]; Barro, [6]; Barro and Lee, [7] [8]; Barro and Sala-i-Marten, [7]. Ramos, R.J. [9]. Osinubi T. [19] states that education has a very important role because most people who have higher education will always provide a new idea, which is a direct function of HR. Barro, R. J. [5] He also stated that investing in education, studies and conducting training is another form of human capital in order to be able to provide assistance in overcoming existing problems and to be able to achieve long-term economic growth.

The problem of unemployment can be considered very complex to be studied and become an important issue, this is because it can be linked to several indicators. In order to achieve the desired output growth, a macroeconomic policy was created, which has the aim that the unemployment rate has low intensity and has good stability. Kingdon and Knight [16] saw from several economic and social involvements and unemployment in a region or country the impact of erosion of human capital, morbidity, increase in crime, protest and social exclusion. The higher poverty rate is caused by higher unemployment as well, because unemployment can be said to be a very large contributor. Therefore, it is very important to be able to understand a correlation between unemployment and economic growth in order to be able to trigger the best policy in growing the economy of a country or region. 
Unfavorable social conditions that will affect health status include psychological vulnerability, prolonged stress, lack of involvement in social activities, and changing future perspectives that can reduce health status Ranis, G. and Stewart, F. [10]. In addition, income inequality within a region is associated with high mortality rates [11]. Thus it can be said that these social factors are more important than material factors in developed countries, while material factors are more important for poor countries, although access to material needs by poor people in rich countries is limited [12]. Limited access to material and social resources forms a basic theory called the "fundamental cause" theory. This theory places the poor suffer more than the rich in the face of changing disease mechanisms because they do not have anything to protect their health against every possible threat [13]. This fundamental cause theory explains the relationship between income and differences in health levels between nations, although in fact there are other factors that affect the health level of a nation, for example, advances in technology play an important role in determining the level of public health [14]. Another exception to the direct relationship between economic prosperity and good health status is that poor countries such as Cuba and China have better health than other rich countries [15]. Improving the level of health can increase the productivity of the workforce either directly or indirectly through the level of education that can be achieved. The low level of child health has an impact on the child's willingness to attend school, the rate of skipping school, and lack of attention when receiving lessons so that it affects the possibility of the child completing education on time and getting or having a managerial job compared to healthy children [16].

In macro terms, the low level of labor productivity as a result of low education caused by low levels of health will affect the low level of national economic growth. Based on the description above, it can be seen that the level of public health and education can affect the economic growth of a nation. The influence of the level of health on economic growth can be directly or indirectly through its effect on the level of public education. Ramos, R. J. [9], Stating where human development and economic development have two directions can be said to be very strong.

We can define UNDP human development as a process to expand people's choices to make improvements to their education experience, employment, income and health care. HDI (Human Development Index) is one way that can measure or see the development of human resources whether it has led to a successful condition. Economic growth provides an offer on how to be able to provide support for improvements in sustainable human development.
Sustainable development Sustainable development on the value of human development is a very important determinant of economic growth.

\section{METHOD}

In this study, in order to avoid deviations from the problem, the authors discuss the effect of education, unemployment, health levels, and the human development index on economic development in and the human development index on economic growth in the 2009-2018 period which aims to realize how the influence between each existing variable.

This study is a quantitative study. The data used in this study is secondary data from 2009-2018. In this study using econometric analysis on multiple regression. This study includes the independent variables, namely education, unemployment, health levels, and the human development index, while the dependent variable is economic growth. The data used, analyzed quantitatively using multiple linear regression statistical analysis. We can state the independent variables that are able to have an influence on the dependent variable in the following equation:

$$
Y=f(X 1, X 2, X 3, X 4, X 5) .
$$

Then the function is transformed into a multiple regression model with the following specifications:

$$
\begin{gathered}
e y=\beta 0 \cdot e \beta 1 X 1+\beta 2 X 2+\beta 5 X 5+\mu \cdot X 3 \beta 3 \cdot X 4 \beta 4 \\
Y=\operatorname{Ln} \beta 0+\beta 1 X 1+\beta 2 X 2+\beta 3 \operatorname{LnX} 3+\beta 4 \operatorname{Ln} X 4+\beta 5 X 5+\mu
\end{gathered}
$$

\section{DISCUSSION}

Effect of human development index, education, health and unemployment rate on economic growth in 2009-2018 period can be seen from multiple regression analysis. In this study, the authors use hypothesis testing, namely simultaneous test and partial test.

\subsection{Simultaneous Testing (F Test)}

Table 1. Interview Result

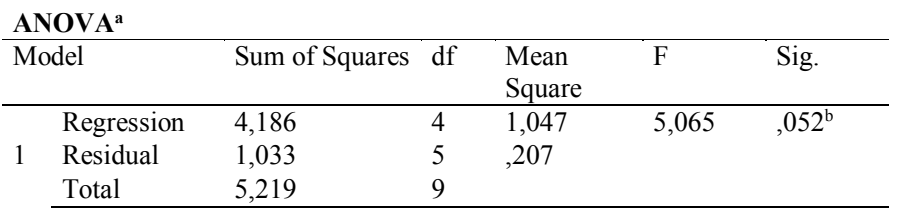

a. Dependent Variable: economic growth

b. Predictors: (Constant), human development index, Education, health, unemployment

In the previous table it can be seen where the significant value of $F$ is 0.052 and the calculated $F$ is 5.065. The value of $F$ table based on statistics is 4.76 . Thus, it can be concluded that $\mathrm{F}$ is significant $0.052<=$ 
0.005 and F count: $5.065>$ ftable: 4.76 , so it can be concluded that the variables of education, unemployment, health level, and The human development index turns out to have a significant effect on economic development.

\subsection{Partial Testing (t Test)}

Table 2. Interview Result

\begin{tabular}{|c|c|c|c|c|c|c|}
\hline \multicolumn{7}{|c|}{ Coefficients $^{\mathbf{a}}$} \\
\hline \multirow{3}{*}{\multicolumn{2}{|c|}{ Model }} & \multirow{2}{*}{\multicolumn{2}{|c|}{$\begin{array}{l}\text { Unstandardized } \\
\text { Coefficients }\end{array}$}} & \multirow{3}{*}{$\begin{array}{l}\text { Standardized } \\
\text { Coefficients } \\
\text { Beta }\end{array}$} & \multirow[t]{3}{*}{$\mathrm{t}$} & \multirow[t]{3}{*}{ Sig. } \\
\hline & & & & & & \\
\hline & & B & $\begin{array}{l}\text { Std. } \\
\text { Error }\end{array}$ & & & \\
\hline \multirow{5}{*}{1} & $\begin{array}{l}\text { (Constan } \\
\text { t) }\end{array}$ & 69,860 & 39,172 & & 1,783 & ,135 \\
\hline & $\begin{array}{l}\text { Educatio } \\
\mathrm{n}\end{array}$ &,- 085 & ,060 &,- 832 & $-1,422$ &, 214 \\
\hline & $\begin{array}{l}\text { Unemploy } \\
\text { ment }\end{array}$ &, 217 & ,417 & ,485 & ,520 & ,625 \\
\hline & $\begin{array}{l}\text { Health } \\
\text { Level }\end{array}$ &,- 400 & ,531 &,- 439 &,- 753 & ,485 \\
\hline & $\begin{array}{l}\text { Human } \\
\text { Developm } \\
\text { ent Index }\end{array}$ &,- 404 &, 105 &,- 881 & $-3,864$ & ,012 \\
\hline
\end{tabular}

a. Dependent Variable: economic growth

1) The constant value (a) has a constant value of 69.860 which means that if there is no influence of the variables of education, unemployment, health levels, and the human development index which are considered constant, the variable of economic growth is 69.860 in South Sulawesi during the 20092018 period.

2) The significant value for the education variable is 0.214 where education is higher than 0.05 , therefore a conclusion can be drawn where economic growth is not partially affected by unemployment

3) The significant value for the unemployment variable is 0.625 , which means that unemployment is greater than 0.05 , so it can be concluded that unemployment has no partial effect on economic growth.

4) The significant value for the health level variable is 0.485 that the level of health is higher than 0.05, which can be drawn a conclusion, namely the health level has no partial effect on economic growth.

5) The significant value for the human development index variable is 0.012 that the human development index is below 0.05 , therefore we can draw a conclusion where the human development index has a significant effect on economic growth.
From the results of data analysis and hypothesis testing that has been carried out in this study, it was found that the education variable has a significance value of 0.214 is higher than 0.05 , therefore we are able to draw a conclusion where education does not have an influence on economic growth. The t-count results in the previous table show -1.422 with a t-table of 2.447 . it shows where t-count is smaller than t-table, which indicates that the education variable does not have a significant effect on economic growth. The explanation above proves that education shows a decline in economic growth every year.

The unemployment variable has a significance value of 0.625 which is greater than 0.05 , therefore it can be concluded that economic growth has no effect on the unemployment variable.. The result of t-count shows the value is 0.520 and t-table, which means t-count is smaller than t-table, which indicates that the unemployment variable does not have a significant effect on economic growth. The explanation above proves that unemployment shows a decline in economic growth every year.

The health level variable has a value of 0.625 which is higher than 0.05, therefore it can be drawn a conclusion that economic growth cannot be influenced by the health level variable. The results of the t-count show a value of -0.753 and the $t$-table, which means $t$ count is smaller than $t$ table which shows that economic growth cannot be influenced by the health level variable. The explanation above proves that the level of health shows a decline in economic growth every year.

The human development index variable has a value of 0.625 which is higher than 0.05 , therefore we can conclude that the unemployment variable does not has had an effect on economic development. In the results of the t-count shows a value of $-3,684$ and the $t$-table. This means that the $\mathrm{t}$-count is lower than the $\mathrm{t}$-table, therefore we can conclude that the human development index variable has a significant effect on economic growth. This explanation proves that if the human development index has increased, then economic growth will have an increase. This fits the view described by Tsamadias, CP. [17] where economic development and economic growth have a two-way correlation, economic growth will increase human development. Olaniyan, D. A. and Okemakinde, T., [18] also argue that the fairly rapid growth of human development will indirectly have a positive influence on economic growth. However, there are several concepts that explain where economic growth has a dual quality in human development, in the practical process there are several factors that can influence this dual quality. In addition to the factors that influence the dual causation, there are also factors that are able to strengthen which are related to economic 
growth and human development. This is in accordance with what was stated by Yuhendri [13] where the reinforcing factors between economic growth and human development are appropriate economic policies, economic structure, income distribution, asset distribution, high investment, and social capital. If you want to achieve an increase in the quality of human resources, you can get it if you go through several factors in determining the quality of resources, which has been previously studied by research of Hanusek, E., and L. Wößmann, [19] where expanding technical and scientific sources of knowledge can provide an increase in productivity labor and other inputs in production activities. This will have a good impact and increase the value of education and make job training activities capable of forming excellent human capital. Dearden, L. J. Ferri, and C. Meghir, [16] also have the opinion that when a person becomes healthier, has a good education and has good nutrition, this will contribute to economic improvement and will indirectly lead to increased productivity. This shows where economic development can be influenced by the human development index of South Sulawesi Province, this results in an increase in the quality of human resources in an area that has a bearing on the quality of the human development index which is the main capital in economic development and can be increased to become more productive. good again.

\section{CONCLUSION}

a. In accordance with the previous data analysis and the discussion that has been carried out, a conclusion is obtained, namely:

b. The results of the study show that the education variable does not have a significant effect on economic growth in South Sulawesi, meaning that if education increases, it will have an impact on decreasing economic growth.

c. The results show that the unemployment variable does not have an influence on economic development in South Sulawesi.

d. The results show that the health level variable does not have an influence on economic development in South Sulawesi.

e. The results show that the human development index variable has an influence on economic development in South Sulawesi.

\section{ACKNOWLEDGMENTS}

We thank the anonymous reviewers who have provided constructive suggestions for improving this article.

\section{REFERENCES}

[1] Ranis, G. (2004). Human Development and Economic Growth.Yale University (Center Discussion Paper No.887).

[2] Gherghina, R. (2013). The Contribution of education to the economic development process of the states. Journal of Knowledge Management, Economics and Information Technology, 3 (1), 211-223.

[3] Gherghina, R. (2013). The Contribution of education to the economic development process of the states. Journal of Knowledge Management, Economics and Information Technology, 3 (1) 211-223.

[4] Dahl, Gordon B., 2002. Mobility and the Return to Education. Econometrica, 70 (6), 2367-2420.

[5] Barro, R. J. (1998), " Notes of Growth Accounting", National Bureau of Economic Research Working Paper, 6654, pp.1-30.

[6] Barro, R. J. and Lee, J. W. (1993), “ International comparisons of Educational Attainment", Journal of Monetary Economics, 32, pp. 363-394.

[7] Barro, R. J. and Lee, J. W. (1994), " Sources of Economic Growth", Carnegie-Rochester Conference Series on Public Policy, pp. 1-46.

[8] Barro, R. J. and Sala-i-Martin, X. (1995), Economic Growth, New York-Mcgraw-Hill.

[9] Ramos, R. J. (2012). Regional economic growth and human capital: the role of over-education. Regional Studies, 1389-1400.

[10] Ranis, G. and Stewart, F. (2005). Dynamic Links between the Economy and Human Development (Working Papers No.8).United Nations, Department of Economic sand Social Affairs.

[11] Howitt, P., and P. Aghion, 1998. Capital Accumulation and Innovation as Complementary Factors in Long-Run Growth. Journal of Economic Growth, 3 (2), 111130

[12] Alqarout, A. (2013), Higher education in the Gaza Strip, Policies, Quality, Access and the Role of NGOs, European Access Network (EAN) Congress Scholar 2013, PP. 1-15.

[13] Yuhendri. (2013). Effect of Quality of Education, Health, Economic Growth and Investment of the West Sumatra. Thesis Padang State University.

[14] Meier, G. M. and Rauch, J. E. (2000). Leading Issues in Economic Development (seventhedition).New York: Oxford University Press.

[15] Ehrhart, C. (2009). The Effects of Inequality on Growth: A Survey of the Theoretical and Empirical Literature. ECINEQWP, p.107.

[16] Dearden, L., J. Ferri, and C. Meghir, 2002. The Effect of School Quality on Educational Attainment and Wages. The Review of Economic and Statistics, 84 (1), 1-20 
[17] Tsamadias, C. P. (2012). The effect of education on economic growth in Greece over the 19602000 period, Education Economics, 20(5), 522-537/

[18] Olaniyan, D.A. and Okemakinde T., 2008. Human Capital Theory: Implications for Educational Development. European Journal of Scientific Research, 24 (2), 157-162.

[19] Hanusek, E., and L. Wößmann, 2008. Education and Economic Growth, Chapter prepared for the International Ency-clopedia of Education, 3rd ed. Available at www.hanushek.net. Accessed at 20 March 2011.

[20] Berg, Hendrik, V. D., 2005. Economic Growth and Development: An Analysis of Our Greatest Economic Achievement and Our Mos Exciting Challenges. New York: Mc-Graw Hill. 